\title{
CBF1 Orthologs in Sour Cherry and Strawberry and the Heterologous Expression of $C B F 1$ in Strawberry
}

\author{
Christopher L. Owens, ${ }^{1}$ Michael F. Thomashow, ${ }^{2}$ James F. Hancock, ${ }^{1}$ and Amy F. Iezzoni ${ }^{1}$ \\ Michigan State University, East Lansing, MI 48824
}

\begin{abstract}
ADDITIONAL INDEX WORDS. cold acclimation, freezing tolerance, pistil, Prunus cerasus, Fragaria $\times$ ananassa
Abstract. Orthologs of $C B F 1$, a cold-induced transcription factor important in the cold acclimation response in Arabidopsis thaliana were cloned from strawberry (Fragaria $\times$ ananassa Duchesne) and sour cherry (Prunus cerasus L.) with degenerate PCR primers. The putative orthologs [Fragaria $\times$ ananassa $C B F 1(F a C B F 1)$ and Prunus cerasus $C B F 1$ (PcCBF 1)] have $48 \%$ amino acid identity to $C B F 1$ and $\mathrm{mRNA}$ levels were up-regulated in leaves of both crops following exposure to $4{ }^{\circ} \mathrm{C}$ from 15 minutes to 24 hours. However, mRNA of $F a C B F 1$ and $P c C B F 1$ was not detected in pistils of strawberry and sour cherry following $4{ }^{\circ} \mathrm{C}$ exposure. Agrobacterium-mediated transformation of a $\mathrm{CaMV35S}$ - $\mathrm{CBF} 1$ construct was conducted on Fragaria $\times$ ananassa 'Honeoye' crown discs. Two transgenic lines were regenerated that expressed the transgene at low levels in both leaves and receptacles. Receptacles of the transgenic lines showed no significant change in freezing tolerance when compared to wild type plants, although the temperature at which $50 \%$ electrolyte leakage occurred in detached leaf discs from the two transgenic lines was $-8.2{ }^{\circ} \mathrm{C}$ and $-10.3{ }^{\circ} \mathrm{C}$, respectively. These freezing tolerance values were significantly greater than the value for the wild-type 'Honeoye' leaf discs of $-6.4{ }^{\circ} \mathrm{C}$.
\end{abstract}

Low temperature is one of the most important environmental factors limiting crop plant growth, distribution, and productivity (Sakai and Larcher, 1987). Plant species differ greatly in their ability to develop freezing tolerance through a process known as cold acclimation (Thomashow, 1999). Traditional breeding of many major crops has met with only limited success in improving freezing tolerance. For example, the freezing tolerance of wheat cultivars has not been substantially improved in the past 50 years (Fowler and Gusta, 1979). As a result, considerable effort has been spent to understand the nature of cold acclimation, in the hopes that novel strategies for improving crop freezing tolerance may be developed.

Many physiological and biochemical changes occur in plants in response to low temperature, including changes in gene expression (Alberdi and Corcuera, 1991). Many cold-induced genes have been identified in several crop species, including alfalfa (Medicago sativa), spinach (Spinacia oleracea), barley (Hordeum vulgare), and peach (Prunus persica) (Guy et al., 1985; Hong et al., 1992; Monroy et al., 1993; Wisniewski et al., 1999). In Arabidopsis thaliana, studies of the molecular basis of cold acclimation have identified a common cis-acting regulatory element, the C-repeat/Dehydration Responsive Element (CRT/DRE) that has the conserved core sequence CCGAC, and found within the promoters of several cold induced (COR) genes (Stockinger et al., 1997). This element is present in one to multiple copies in the promoters of many cold-induced plant genes, including COR6.6, COR15a, COR47, and COR78 of arabidopsis and BN115 of Brassica napus (Baker et al., 1994; Jiang et al., 1996; Stockinger et al., 1997; Yamaguchi-Shinozaki and Shinozaki 1994). In turn, all of the currently characterized arabidopsis COR genes are coordinately up-regulated by $\mathrm{CBF} 1, \mathrm{CBF} 2$, or $\mathrm{CBF} 3$, a family of cold and drought inducible transcriptional activators that bind to promoters containing a CRT/DRE (Jaglo-Ottosen et al., 1998; Kasuga et al., 1999; Liu et al., 1998; Thomashow et al., 2001). Even though freezing tolerance is a complexly inherited

Received for publication 7 Feb. 2002. Accepted for publication 8 Apr. 2002. We thank Sarah J. Gilmour for technical assistance and for supplying arabidopsis DNA and probes.

${ }^{1}$ Department of Horticulture.

${ }^{2}$ Department of Crop and Soil Science and Department of Microbiology. trait, manipulation of just one gene, $C B F 1$, has been shown to improve the whole plant freezing tolerance of arabidopsis (JagloOttosen et al., 1998). Because CBF genes are key regulators of cold acclimation and overexpression of $C B F 1,2$, or 3 is capable of improving the freezing tolerance of arabidopsis, there is significant interest in determining if orthologs of the $C B F$ gene family exist in cultivated species and function in a similar fashion to improve freeze tolerance.

The distribution of many temperate fruit crops is restricted by low temperature stress. Floral damage is often the main form of freeze injury, particularly in several of the early blooming members of the Rosaceae (e.g., strawberry (Fragaria Xananassa), cherry (Prunus avium and P. cerasus), peach, almond (Prunus dulcis), apricot (Prunus armeniaca) ) (Rodrigo, 2000). Many cultural techniques are used to mitigate the damage caused by freezes during bloom (Rieger, 1989). However, improved cultivars with enhanced floral freezing tolerance would be of considerable interest to help prevent crop loss caused by freeze damage and to help stabilize yearly yield fluctuations.

One approach to develop cultivars with enhanced freezing tolerance is to identify and use candidate genes playing important roles in this trait. It is plausible that cold-induced genes exist within the Rosaceae that are orthologous to those in arabidopsis capable of improving freezing tolerance. Whether these genes can be used, through either biotechnological manipulation or exploitation of natural variation, to improve floral freezing tolerance in rosaceous crops is unknown. It is also unknown if the same relationship exists between cold-induced gene expression and onset of cold-acclimation in rosaceous flowers.

The interaction between low temperature and photoperiod on cold acclimation of woody fruit crops has been extensively studied (Howell and Weiser, 1970; Weiser, 1970), and it is known that the over-wintering structures of perennial, temperate fruit crops possess the ability to cold acclimate. When tested under controlled conditions, detached pistils from sour cherry (Prunus cerasus) do not appear to have the ability to cold acclimate (C. Owens, unpublished results). In contrast, receptacles with attached pistils of strawberry show an improvement in freezing tolerance of $\approx 2$ to $3{ }^{\circ} \mathrm{C}$ following whole plant exposure to $4{ }^{\circ} \mathrm{C}$ for $16 \mathrm{~d}$ (C. Owens, unpublished results). If orthologs of the $C B F$ gene family can be identified in strawberry and sour cherry, the 
Table 1. Degenerate PCR primers used to clone $C B F$ orthologs.

\begin{tabular}{lll}
\hline \hline Primer & Forward $^{\mathrm{z}}$ & Reverse \\
\hline CBF degenerate & CCNAARAARCCNGCNGGNAG & GGNARNARCATNCCYTCNGCC \\
CBF degenerate nested & CCNAARAARCCNGCNGGNAG & TCNGCRAARTTYAARCA \\
\hline
\end{tabular}

${ }^{\mathrm{z}}$ Degenerate nucleotides were $\mathrm{N}=(\mathrm{AGTC}), \mathrm{R}=(\mathrm{AG}), \mathrm{Y}=(\mathrm{CT}), \mathrm{K}=(\mathrm{GT}), \mathrm{M}=(\mathrm{AC})$.

relationship between expression of these $C B F$ orthologs and cold acclimation in pistils of both crops can be determined.

The objectives of this study were to identify orthologs of the $C B F$ gene family in strawberry and sour cherry, determine if any putative orthologs were expressed in response to low temperature in either leaves and/or pistils of these two crops, and to determine the effects of overexpression of $C B F 1$ from arabidopsis on the freezing tolerance of cultivated strawberry vegetative and reproductive tissues.

\section{Materials and Methods}

Plant material and growth conditions. Containerized, dormant, rooted runners of 'Honeoye' Fragaria xananassa as well as 3 year old, dormant plants grown from rooted cuttings of 'Montmorency' Prunus cerasus were grown in controlled environment chambers maintained at $24^{\circ} \mathrm{C} / 18^{\circ} \mathrm{C}$ with 14 h daylengths at $800 \mathrm{mmol} \cdot \mathrm{m}^{-2} \cdot \mathrm{s}^{-1}$ photosynthetically active radiation (PAR) and $10 \mathrm{~h}$ nights until the onset of flowering. Four degree cold treatments were administered by transferring plants to a chamber maintained at a constant $4{ }^{\circ} \mathrm{C}$ with $14 \mathrm{~h}$ daylengths at 200 $\mathrm{mmol} \cdot \mathrm{m}^{-2} \cdot \mathrm{s}^{-1} \mathrm{PAR}$ and $10 \mathrm{~h}$ nights.

DNA EXTRACTIONS, RNA EXTRACTIONS, SOUTHERNS, AND NORTHERNS. Genomic DNA was extracted from young strawberry leaflets by grinding fresh tissue under liquid nitrogen, homogenizing in buffer containing $2 \% \mathrm{CTAB}, 100 \mathrm{~mm}$ Tris, $1.4 \mathrm{M} \mathrm{NaCl}$, $20 \mathrm{~mm}$ EDTA, $0.1 \%$ DTT, 1\% PVPP, extracting with chloroform/isoamyl alcohol, and precipitating once with isopropanol, and a second time with 70\% ethanol (Graham et al., 1994).

RNA extractions followed the protocol reported by Tao et al. (1999). Total RNA was extracted from both young, developing sour cherry and strawberry leaflets, pistils and receptacles from fully open flowers by grinding fresh tissue under liquid nitrogen, homogenizing in 25 phenol : 24 chloroform : 1 isoamyl alcohol (by volume), mercaptoethanol, and $0.1 \mathrm{~m}$ Tris ( $\mathrm{pH} 9.0), 0.1 \mathrm{~m}$ $\mathrm{LiCl}, 1 \% \mathrm{SDS}$, and $10 \mathrm{~mm}$ EDTA. The aqueous phase was extracted with 25 phenol : 24 chloroform : 1 isoamyl three times, and then precipitated with $\mathrm{LiCl}$ at a final concentration of $4 \mathrm{M}$ overnight at $-20^{\circ} \mathrm{C}$. The RNA was recovered, resuspended, and precipitated with 3 м sodium acetate and ethanol.

Northern transfers were made by fractionating $20 \mu \mathrm{g}$ of total RNA in 1\% agarose formaldehyde gels (Sambrook and Russell, 2001) and transfer to nylon membranes by capillary action. The filters were hybridized with randomly primed ${ }^{32} \mathrm{P}$-labeled probes. Probes were made from full-length cDNA of $C B F 1$. eIF4a was used to probe the northern membranes to determine even loading of RNA. Final stringency of the washes was at $60{ }^{\circ} \mathrm{C}$ with $0.1 \times$ SSC and $0.1 \%$ SDS.

Southern transfers were made by fractionating $6 \mu \mathrm{g}$ of genomic DNA digested overnight at $37^{\circ} \mathrm{C}$ with HindIII in $1 \%$ agarose gels (Sambrook and Russell, 2001) and transfer to nylon membranes. The filters were hybridized with randomly primed ${ }^{32} \mathrm{P}$-labeled probes using full-length $C B F 1 \mathrm{cDNA}$ as template. Final stringency of the washes was at $60{ }^{\circ} \mathrm{C}$ with $0.1 \times \mathrm{SSC}$ and $0.1 \%$ SDS.
Degenerate Primer PCR, InVERSE PCR (iPCR), SEQUenCing. Degenerate primers for CBF were designed by aligning CBF or putative CBF orthologs from Arabidopsis thaliana (Stockinger et al., 1997), Brassica napus (Zhou et al., GenBank accession AF084185), and Nicotiana tabacum (Durrant et al., GenBank accession AAG43548). Three regions of similarity were found between these sequences and used to design nested primers for PCR. The degenerate primers used to amplify partial genomic fragments of putative $C B F$ orthologs in strawberry and sour cherry are listed in Table 1.

The first round of amplification was run with the first set of primers reported in Table 1. Reactions were carried out in $25-\mu \mathrm{L}$ volumes at final concentrations of buffer $(10 \mathrm{~mm}$ Tris, $50 \mathrm{~mm} \mathrm{KCl}$, $0.001 \%$ gelatin, $\mathrm{pH} 8.3$ ), $0.05 \mathrm{~mm}$ dNTPs, $0.4 \mu \mathrm{m}$ each primer, 3.0 $\mathrm{mm} \mathrm{MgCl}_{2}, 0.04 \mathrm{U} / \mu \mathrm{L} \mathrm{Taq}$ polymerase, and $100 \mathrm{ng}$ genomic DNA as template. Reactions using arabidopsis genomic DNA were included as positive controls. The reactions were run at $94{ }^{\circ} \mathrm{C}$ for $5 \mathrm{~min}$, followed by 35 cycles of $94^{\circ}$ for $1 \mathrm{~min}, 50^{\circ} \mathrm{C}$ for $1 \mathrm{~min}$, and $72{ }^{\circ} \mathrm{C}$ for $1 \mathrm{~min}$, with a final elongation of $72^{\circ} \mathrm{C}$ for $5 \mathrm{~min}$. One microliter of these reaction products were then used as template for a nested PCR reaction possessing the same conditions as listed above, but using the nested primer pair (Table 1).

PCR products of interest were excised from $1.0 \%$ low-melting point agarose, and purified with a gel extraction kit (Qiagen Corp., Valencia, Calif.). Purified PCR products were then cloned into the vector pGEM-T Easy (Promega Corp., Madison, Wis.) and sequenced once in both the $5^{\prime}$ and $3^{\prime}$ directions by the Michigan State University Genomics Technology Support Facility using BigDye cycle-sequencing on an ABI PRISM 3100 (Applied Biosystems, Inc., Foster City, Calif.).

The resultant sequence was then used to design inverse PCR (iPCR) primers for obtaining flanking genomic sequence of the fragment already obtained. The iPCR protocol followed a modified version of the protocol reported by Willis et al. (1997). One microgram of total genomic DNA was digested with $5 \mathrm{U}$ HindIII in $10 \mu \mathrm{L}$ overnight at $37^{\circ} \mathrm{C}, 1$ phenol : 1 chlorofrom extracted, precipitated in sodium acetate and ethanol, and resuspended in water. Digested DNA (300 ng) was self-ligated at a concentration of $0.5 \mu \mathrm{g} \cdot \mathrm{mL}^{-1}$ and $0.02 \mathrm{U} / \mu \mathrm{L}$ DNA ligase overnight at $15^{\circ} \mathrm{C}$. A nested PCR reaction was then run with $1 \mu \mathrm{L}$ of product from the first reaction as template for the second reaction. Nested PCR products were cloned and sequenced as described above.

STRAWBERRY TRANSFORMATION. Transformation was conducted on crowns from tissue culture stocks of 'Honeoye' Fragaria Xananassa plants that had been maintained for $\approx 20$ weeks on a Murashige and Skoog (MS) salts medium with vitamins, but no hormones $\left(4.3 \mathrm{~g} \cdot \mathrm{L}^{-1} \mathrm{MS}\right.$ salts (GIBCO), $0.5 \mathrm{mg} \cdot \mathrm{L}^{-1}$ nicotinic acid, $0.5 \mathrm{mg} \cdot \mathrm{L}^{-1}$ pyridoxine, $0.1 \mathrm{mg} \cdot \mathrm{L}^{-1}$ thiamine, $2 \mathrm{mg} \cdot \mathrm{L}^{-1}$ glycine, 100 $\mathrm{mg} \cdot \mathrm{L}^{-1}$ myo-inositol, $20 \mathrm{~g} \cdot \mathrm{L}^{-1}$ sucrose, $8 \mathrm{~g} \cdot \mathrm{L}^{-1}$ agar, $\mathrm{pH}$ 5.6) (Graham et al., 1995). Following transformation and regeneration, rooted explants were transferred to $10 \times 10 \times 20 \mathrm{~cm}$ plastic pots containing sterile, soilless potting media enclosed in a plastic bag, and gradually hardened off by opening the bags slightly each day. Tissue culture plants, regenerants, and rooted plants were maintained at $24^{\circ} \mathrm{C}, 16 \mathrm{~h}$ photoperiods. 
CBF 1

PCCBF

FaCBF

(47) IYRGVRQRNSGKWVSEVREPNKKTR IWLGTFOTAEMAARAHDVAAI (41) VYRGVRRRNSGKWVCEVREPWKKTRIWLGTF PTAEMAARAHDVAAI (44) VYRGVRRRNSGKWVCEVREPNKKTRIWLGTE PTTEMAARAHDVAAI

CBF1 (94) ALRGRSACLNFADSAWRIRIPESTCAKDIQKAAAEAALAFQDETCD PCCBF (88) ALRGRSACLNFAESAWRI PVPASANAKDIQTTASEAAEAFRPPVEG FaCBF (91) ALRGRSACLNFAESAKRLPVRLLIVLRTYRRRLLDAAEAFRPNRGE

\section{CBF1 PCCBF FaCBF \\ CBF 1 PCCBF FaCBF}

at the rate of $4{ }^{\circ} \mathrm{C} \cdot \mathrm{h}^{-1}$. Every $30 \mathrm{~min}$ a set of tubes was transferred to a separate freezing bath kept at the same temperature as the bath it came from, and maintained at that temperature for an additional $30 \mathrm{~min}$ (for a total of $1 \mathrm{~h}$ at each temperature). After $1 \mathrm{~h}$ of freezing, tubes were placed on ice until the completion of the freezing experiment. Freezing runs were carried out to a final temperature of $-20{ }^{\circ} \mathrm{C}$.

Following completion of the freezing run, tubes were placed in a rack on top of ice, wrapped with plastic, and kept at $4{ }^{\circ} \mathrm{C}$ overnight. Following thawing, $3 \mathrm{~mL}$ of deionized, distilled water was added to each tube, and the tubes were then shaken for $3 \mathrm{~h}$. Electrical conductivity of the water was measured from each tube with a bench-top electrical conductivity meter (Corning 441, Acton, Mass.), the plant material in the tubes was placed at $-80^{\circ} \mathrm{C}$ for $1 \mathrm{~h}$, and the original water was then added back to each tube for an additional $3 \mathrm{~h}$, with agitation. A final electrical conductivity was then determined for the water in each tube.

Three sets of data points were generated for each temperature point of the freezing run, with three tubes representing each data point. These data were used to generate an electrolyte leakage curve over the range of temperatures used in the freezing run. Three to four curves were generated per treatment.

\section{Results}

Nested, degenerate primer-PCR yielded small, 225-bp fragments from strawberry 'Honeoye' and sour cherry 'Montmorency' genomic DNA that were the same size as the predicted fragment from arabidopsis genomic DNA. This fragment was predicted to contain the entire AP2 domain plus a small 5' portion of the gene

Fig. 2. $P C C B F$ and $F a C B F$ transcript levels determined by northern analysis in leaves and pistils of sour cherry 'Montmorency' and leaves and receptacles of strawberry 'Honeoye' following $0 \mathrm{~h}, 1 \mathrm{~h}, 4 \mathrm{~h}$, and $24 \mathrm{~h}$ of exposure to $4{ }^{\circ} \mathrm{C}$. Eukaryotic initiation factor $4 \mathrm{a}(e I F 4 a)$ was used as a RNA loading control. nontransformed 'Honeoye' plants that had been regenerated from crown discs in a similar fashion to the transgenics.

DETERMINATION OF FREEZING TOLERANCE. Freezing tolerance was determined on detached strawberry leaf discs by electrolyte leakage (Sukumaran and Weiser, 1972). Leaf discs were detached from the whole plant, and stored in deionized, distilled water until all had been placed in $16 \mathrm{~mm}$ diameter $\times 125$ $\mathrm{mm}$ long glass culture tubes. Three leaf discs were placed in each culture tube. Data from three tubes were pooled for each temperature point of the controlled freezing run.

Freezing runs were conducted by placing the tubes in freezing-water baths containing a mixture of ethylene glycol and water. The tubes were maintained at $0{ }^{\circ} \mathrm{C}$ for $1 \mathrm{~h}$, after which a small amount of deionized ice was placed in contact with the plant material in each tube to nucleate ice formation. The tubes were kept for an additional hour at 0 ${ }^{\circ} \mathrm{C}$, and the temperature was then decreased

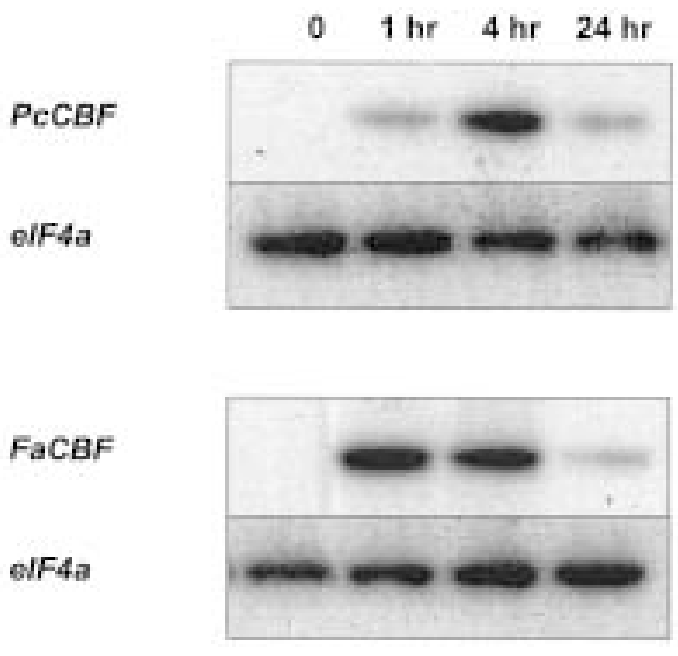

Leaves
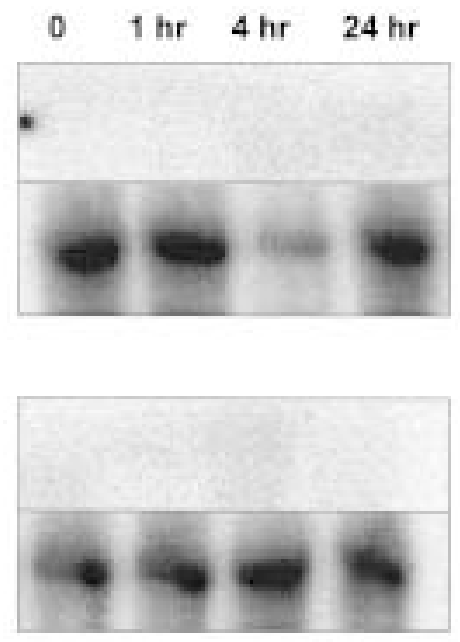

Pistils/Receptacles 
Fig. 3. Southern analysis of wild-type and 35-1-1 and 35-1-2 'Honeoye' strawberry plants transformed with $C B F 1$. Restriction digestion conducted with HindIII.

based on the position of the nested PCR primers. Sequencing of the cloned fragments revealed that the degenerate PCR products had predicted $\approx 95 \%$ amino acid identity to the AP2 domain of CBF1 with a small portion 5 ' to the AP2 domain (data not shown). Nested primers were designed from this sequence and iPCR reactions yielded fragments ranging from 1 to $1.5 \mathrm{~kb}$ in length. Sequencing of these fragments produced ORFs that contained the bulk of the predicted amino acid coding region of these genes (Fig. 1). These putative orthologs were named Prunus cerasus $C B F 1$ (PcCBF1) and Fragaria $\times$ ananassa CBF1 (FaCBF1).

Northern analyses were conducted to determine the effects of 4 ${ }^{\circ} \mathrm{C}$ treatment on the mRNA expression (i.e., steady state transcript levels) of $P c C B F 1$ and $F a C B F 1$. No expression of these two genes was evident in nonacclimated leaf tissue of either species (Fig. 2). Following whole plant exposure to $4{ }^{\circ} \mathrm{C}$ for $1 \mathrm{~h}$, a low level of expression of $P C C B F 1$ was observed in sour cherry leaves, and a high level of expression of $F a C B F 1$ in strawberry leaves. Of the time points measured in this experiment, $4 \mathrm{~h}$ of $4{ }^{\circ} \mathrm{C}$ treatment yielded the highest level of expression for both $P c C B F 1$ and $F a C B F 1$ in sour cherry and strawberry leaves, respectively. Expression appeared to taper off after $4 \mathrm{~h}$ of cold treatment, as mRNA steady-state expression level was reduced after $24 \mathrm{~h}$ of exposure to $4{ }^{\circ} \mathrm{C}$ in both strawberry and sour cherry leaves.

No $P c C B F 1$ or $F a C B F 1$ expression was detected by northern analysis in either sour cherry pistils or strawberry receptacles in any of the treatments of $4{ }^{\circ} \mathrm{C}$ (Fig. 2).

Two transgenic strawberry lines transformed with a $C a M V$ 35S-CBF1 construct and designated 35-1-1 and 35-1-2 were recovered from the selection medium. PCR results confirmed the presence of the transgene in these two lines (data not shown). Southern analysis with a full-length $C B F 1$ cDNA as probe revealed single bands in the two transgenic lines (Fig. 3). These lines were first-generation transformants.

Northern analysis of the two transgenic lines probed with a full-length $C B F 1$ cDNA showed expression of the transgene in both actively growing leaf tissue as well as receptacle tissue of fully open flowers (Fig. 4).

The freezing tolerance of leaf discs and receptacle tissues was determined for the two transgenic lines. Both lines showed a significant increase in freezing tolerance of leaf discs compared to the wild type plants when measured by electrolyte leakage (Table 2). The temperature at which $50 \%$ electrolyte leakage occurred was $-8.2^{\circ} \mathrm{C}$ and $-10.4{ }^{\circ} \mathrm{C}$ for nonacclimated lines $35-1$ 1 and $35-1-2$, respectively. These values were $\approx 4$ to $5^{\circ} \mathrm{C}$ below the freezing tolerance of wild type leaf discs. Leaf discs taken from transgenic whole plants exposed to $4{ }^{\circ} \mathrm{C}$ for $16 \mathrm{~d}$ showed a less significant increase in freezing tolerance when compared to wild type plants. All plants showed a significant increase in freezing tolerance following $16 \mathrm{~d}$ of exposure to $4{ }^{\circ} \mathrm{C}$, when compared to nonacclimated plants.

Freezing tolerance values of the receptacles and pistils of the transgenic lines were not significantly different from those of wild type plants acclimated for $16 \mathrm{~d}$ or for $0 \mathrm{~d}$ (Table 2 ).

\section{Discussion}

The putative CBF1 orthologs identified in this study have $48 \%$ deduced amino acid sequence identity with the characterized CBF 1, 2, and 3 proteins from arabidopsis. These proteins have very high similarity through the entire AP2 domain. There are several additional conserved stretches: a PKKPAGRK 5' to the AP2 domain, a AWRL 3 ' to the AP2 domain, and a NMAEGMLLPP near the carboxy terminus. Similar conserved regions have been reported for $\mathrm{CBF}$-like proteins from Secale cereale, Brassica napus, Triticum aestivum, and Solanum lycopersicon (Jaglo et al., 2001). The mRNA expression profile in response to cold appears to be very similar to that observed in arabidopsis. The $C B F$ gene family of arabidopsis is up-regulated very quickly in response to low temperature, with mRNA expression observed after $15 \mathrm{~min}$ of exposure to $4^{\circ} \mathrm{C}$ (Gilmour et al., 1998). mRNA expression peaked $\approx 4 \mathrm{~h}$ after constant $4{ }^{\circ} \mathrm{C}$ and then gradually tails off, often being low, but present after $24 \mathrm{~h}$ of constant $4{ }^{\circ} \mathrm{C}$ treatment (Gilmour et al., 1998). The strawberry and sour cherry $C B F 1$ orthologs described here have a similar mRNA expression profile, at least in vegetative tissues. $F a C B F 1$ and $P C C B F 1$ are up-regulated within $1 \mathrm{~h}$ of exposure to $4^{\circ} \mathrm{C}$, appear to have peaked as early as $4 \mathrm{~h}$, and then decrease substantially, but are still present after $24 \mathrm{~h}$. Gene expression at time points beyond $24 \mathrm{~h}$ of exposure to $4^{\circ} \mathrm{C}$ was not measured in these experiments.

One fundamental question is: are the $C B F$ gene family members central to cold acclimation in higher plants? Arabidopsis has three cold-induced $C B F$ genes that are linked in tandem, have high sequence identity with each other, and thus far appear to have redundant functions (Gilmour et al, 1998; Medina et al., 1999). It is currently unknown what effect the silencing or the mutation of these genes will have on the capability of arabidopsis to acclimate. Despite the lack of $F a C B F 1$ expression in strawberry receptacles, these organs are capable of cold acclimation (Owens, unpublished results) (Table 2). Strawberry receptacles may be a system in which $C B F 1$ expression is not evident, but cold acclimation does occur. Alternatively, another $C B F$ family member may be expressed that is not detectable with the probe and stringency level reported here.

Several general approaches could be taken to use the information obtained in this study to ultimately improve the floral freezing tolerance of rosaceous fruit cultivars. One fundamental question is, why do strawberry and sour cherry pistils acclimate less so, or not at all, while the leaves acclimate to a greater extent? Differential expression of $C B F$ orthologs may help explain the difference between these two tissues. Putative cold-inducible

Leaves. Receptacles/Pistils

\section{5-1-1 35-1-2 wt 35-1-1 35-1-2 wt}

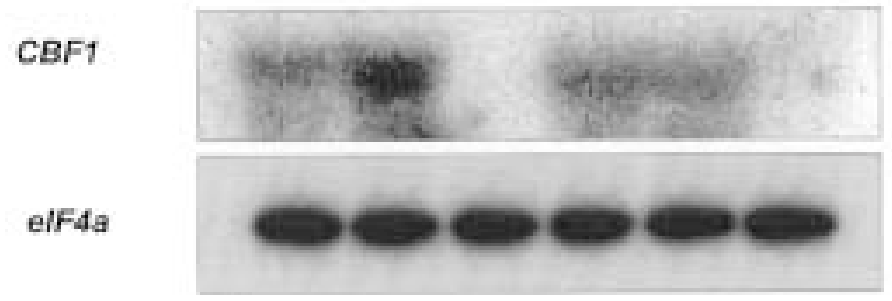

Fig. 4. $C B F 1$ transcript levels in wild-type plants and 35-1-1 and 35-1-2 transgenic plants that overexpress $C B F 1$. Eukaryotic initiation factor $4 \mathrm{a}(e I F 4 a)$ was used as a RNA loading control. 
Table 2. Temperature at which 50\% electrolyte leakage occurred for wild-type 'Honeoye' plants and lines 35-1-1 and 35-1-2, which overexpress $C B F 1$.

\begin{tabular}{lcccc}
\hline \hline & \multicolumn{2}{c}{ Nonacclimated } & \multicolumn{2}{c}{ Acclimated $^{2}$} \\
\cline { 2 - 5 } Plant & $\begin{array}{c}\text { Leaf } \\
\text { discs }\end{array}$ & $\begin{array}{c}\text { Receptacles } \\
+ \text { pistils }\end{array}$ & $\begin{array}{c}\text { Leaf } \\
\text { disks }\end{array}$ \\
\hline Wild type & $-4.8 \mathrm{a}$ & -2.0 & -12.3 & -13.4 \\
$35-1-1$ & $-8.3 \mathrm{~b}$ & -2.6 & -13.8 & -5.1 \\
$35-1-2$ & $-10.4 \mathrm{c}$ & -2.1 & NS & -5.6 \\
F test within column & $* *$ & NS & NS \\
\hline
\end{tabular}

zacclimated whole plants exposed to $4{ }^{\circ} \mathrm{C}$ for $16 \mathrm{~d}$.

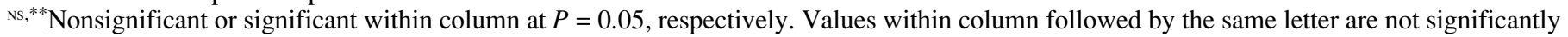
different at $P=0.05$ by LSD.

orthologs of at least $C B F 1$ exist within the Rosaceae, but do not appear to be expressed in pistils of either strawberry or sour cherry. Nonetheless, strawberry receptacles and pistils appear to have the ability to cold acclimate in the absence of $C B F 1$ expression (Table 2). If the ability of these organs to acclimate is not due to $C B F 1$ expression, an elucidation of the molecular mechanisms leading to improved floral freezing tolerance of strawberry following exposure to cold temperature could lead to novel methods for improving floral freezing tolerance in this crop. In contrast, in sour cherry, in which pistil cold acclimation is not evident, an interesting question is what differs between strawberry and sour cherry that prevents sour cherry pistils from acclimating in response to cold? An additional approach would be to observe the effects of $C B F 1$ overexpression on sour cherry pistil freezing tolerance. In short, studies on the mechanism of cold acclimation in strawberry receptacles, or the reason why strawberry and sour cherry pistils vary in their ability to acclimate may provide information useful for the development of cultivars with enhanced floral freezing tolerance.

The level of freezing tolerance enhancement observed in this study between strawberry plants expressing $C B F 1$ and the wildtype, nontransgenic regenerated 'Honeoye' plants is of a similar order of magnitude as that observed between transgenic and wild type arabidopsis (Gilmour et al., 2000; Jaglo-Ottosen et al., 1998). A range of freezing tolerance values has been observed among different transgenic arabidopsis lines often showing about a 3 to $4{ }^{\circ} \mathrm{C}$ decrease in the $50 \%$ electrolyte leakage point of detached leaves between nonacclimated transgenic and wild type plants. Although data from a large number of transgenic lines hve not been reported, there often appears to be a positive correlation between transgene expression and degree of freezing tolerance enhancement (Gilmour et al., 2000; Jaglo-Ottosen et al., 1998). In this study, only two transgenic lines with similar transgene expression levels were identified and they had similar freezing tolerances. Also, experiments were conducted on first generation transformants. Therefore, the possibility of chimerical plants exists and crosses should be made to determine if the effect on freezing tolerance is due to an interaction between tissue layers.

No enhancement in freezing tolerance was observed in the receptacle tissue, despite expression of the transgene at similar levels to those observed in developing leaves. The reason for the lack of freezing tolerance improvement in receptacle tissue, despite a significant improvement in leaves, is not known. However, there is evidence from arabidopsis suggesting that some of the genes involved in cold acclimation are not expressed in pistils. In transgenic arabidopsis containing reporter genes driven by the cor $15 a$ and $\operatorname{cor} 78$ promoters, no expression of the reporter was observed in ovaries following whole-plant exposure to $4{ }^{\circ} \mathrm{C}$ despite reporter expression in many vegetative and reproductive tissues (Baker et al., 1994; Horvath et al., 1993). Freezing tolerance of arabidopsis flowers has not been directly measured, but it is possible that the signal transduction steps or components between $C B F$ induction and $C O R$ gene activation are not functional. Evidence for a defect in $C B F$ induction has been suggested for the sfr6 mutant in arabidopsis that is deficient in freezing tolerance following cold acclimation. These mutants do not show expression of COR6.6, COR15a, or COR78 in response to cold temperature, even though $C B F 3$ expression following cold exposure is normal (Knight et al., 1999; McCown et al., 1996; Warren et al., 1996). It has been postulated that SFR6 is required for coldinduced activation of the CBF3 protein. It is possible SFR6 or some as yet unidentified component of the cold acclimation molecular response is functioning differently in pistils and leaves. However, strawberry receptacles appear to be able to acclimate in the absence of expression of a strawberry $C B F$ ortholog (C. Owens, unpublished results) (Table 2). This observation raises the possibility that there is either some differential control in the signal transduction pathway leading to the induction of $C B F$ in strawberry pistils and receptacles, or that cold acclimation is still possible through an alternative pathway, or through a $C B F$ paralog that was undetected in these experiments.

The data reported in this study support the hypothesis that the $C B F-C O R$ gene system is conserved in the Rosaceae. CBF1 is a cold-inducible transcriptional activator that has been shown to increase the freezing tolerance of arabidopsis, when overexpressed, by up-regulating a battery of genes containing CRT/DRE in their promoters (Jaglo-Ottosen et al., 1998). Although, a rosaceous CRT/DRE containing gene was not identified, the enhancement in freezing tolerance suggests there may be an intermediary step in which several CRT/DRE containing proteins are up-regulated leading to the observed enhancement in freezing tolerance.

The probability that the $C B F-C O R$ gene system is conserved in the Rosaceae, is further supported by the identification of putative orthologs of $C B F$ in both strawberry and sour cherry that have similar mRNA expression profiles as the $C B F$ gene family in arabidopsis in response to cold temperature, in vegetative tissues. Additional support for this hypothesis could be gained by the identification of $C O R$ gene orthologs that possess CRT/DRE in their promoters, a demonstration of up-regulation of the $C O R$ gene orthologs by overexpression of either arabidopsis $C B F 1,2$, or 3 , or overexpression of a native $C B F$ from a rosaceous plant. Also, a demonstration of the direct binding of the rosaceous $C B F$ orthologs to the promoters of $C O R$ gene orthologs would provide support for conservation of a similar molecular mechanism involving these genes.

The demonstration of an enhancement in freezing tolerance of an important perennial fruit crop is of major practical significance. In the case of strawberry, freezing damage can occur both 
to flowers, due to its early bloom, and also to the crown tissue of the plant due to midwinter temperatures below its critical threshold for survival. Strawberries have a wide cultivated range, and in colder climates plantings are often mulched to protect them from damaging winter temperatures where snow cover is unpredictable. Additional physiological protection from midwinter temperatures would allow a wider range of cultivars to be grown in cool climates.

Further study is required to determine if manipulation of the $C B F$ system in strawberry, or other fruit crops, is capable of improving the freezing tolerance of pistils. Additional experiments, attempting to develop lines with higher transgene expression levels, or targeted expression directly to the pistils may provide some additional information to answer this question. Significantly, if the $C B F-C O R$ gene system is closely conserved between arabidopsis and rosaceous species, then arabidopsis can be used as a model for elucidating the nature of the cold acclimation molecular signal transduction pathway in these important cultivated plants. Progress will be more rapid in arabidopsis and use of the information generated in this model species will be of major utility to horticultural scientists and breeders of horticultural plants.

\section{Literature Cited}

Alberdi, M. and L.J. Corcuera. 1991. Cold acclimation in plants. Phytochemistry 30:3177-3184.

Baker, S.S., K.S. Wilhelm, and M.F. Thomashow. 1994. The 5'-region of Arabidopsis thaliana cor15a has cis-acting elements that confer cold-, drought-, and ABA-regulated gene expression. Plant Mol. Biol. 24:701713.

Fowler,D.B. and L.V.Gusta. 1979. Selection for winter hardiness in wheat. I. Identification of genotypic variability. Crop Sci. 19:769-772.

Gilmour, S.J., D.G. Zarka, E.J. Stockinger, M.P. Salazar, J.M. Houghton, and M.F. Thomashow. 1998. Low temperature regulation of the Arabidopsis $C B F$ family of AP2 transcriptional activators as an early step in the cold-induced COR gene expression. Plant J. 16:433-442.

Gilmour, S.J., A.M. Sebolt, M.P. Salazar, J.D. Everard, and M.F. Thomashow. 2000. Overexpression of the Arabidopsis CBF3 transcriptional activator mimics multiple biochemical changes associated with cold acclimation. Plant Physiol. 124:1854-1865.

Graham, J., R.J. McNicol, K. Grieg. 1995. Towards genetic based insect resistance in strawberry using the cowpea trypsin inhibitor gene. Ann. Appl. Biol. 127:163-173.

Graham, J., R.J. McNicol, K. Greig, and W.T.G. Vandeven. 1994. Identification or red raspberry cultivars and an assessment of their relatedness using fingerprints produced by random primers. J.Hort. Sci. 69:123-130.

Guy, C.L., K.J. Niemi, and R. Brambi. 1985. Altered gene expression during cold acclimation of spinach. Proc. Natl. Acad. Sci. USA 82:36733677.

Hong, B., R. Barg, T.-H.D. Ho. 1992. Developmental and organ-specific expression of an ABA- and stress-induced protein in barley. Plant Mol. Biol. 18:663-674.

Horvath, D.P., B.K. McLarney, and M.F. Thomashow. 1993. Regulation of Arabidopsis thaliana L. (Heyn) cor 78 in response to low temperature. Plant Physiol. 103:1047-1053.

Howell, G.S. and C.J. Weiser. 1970. The environmental control of cold acclimation in apple. Plant Physiol. 45:390-394.

Jaglo, K.R., S. Kleff, K.L. Amundsen, X. Zhang, V. Haake, J.Z. Zhang, T. Deits, and M.F. Thomashow. 2001. Components of the Arabidopsis Crepeat/dehydration-responsive element binding factor cold-response pathway are conserved in Brassica napus and other plant species. Plant Physiol. 127:910-917.

Jaglo-Ottosen, K.R., S.J. Gilmour, D.G. Zarka, O. Schabenberger, and M.F. Thomashow. 1998. Arabidopsis CBFl overexpression induces COR genes and enhances freezing tolerance. Science 280:104-106.
Jiang, C., B. Iu, J. Singh. 1996. Requirement of a CCGAC cis-acting element for cold induction of the BN115 gene from winter Brassica napus. Plant Mol. Biol. 30:679-684.

Kasuga, M., Q. Liu, S. Miura, K. Yamaguchi-Shinozaki, and K. Shinozaki. 1999. Improving plant drought, salt, and freezing tolerance by gene transfer of a single stress-inducible transcription factor. Nature Biotechnol. 17:287-291.

Knight, H., E.L. Veale, G.J. Warren, and M.R. Knight. 1999. The sfr6 mutation in Arabidopsis suppresses low-temperature induction of genes dependent on the CRT DRE sequence motif. Plant Cell 11:875-886.

Liu, Q., M. Kasuga, Y. Sakuma, H. Abe, S. Miura, K. YamaguchiShinozaki, and K. Shinozaki. 1998. Two transcription factors, DREB1 and DREB2, with and EREBP/AP2 DNA binding domain separate two cellular signal transduction pathways in drought- and low- temperatureresponsive gene expression, respectively, in Arabidopsis. Plant Cell 10:1391-1406.

McKown, R., G. Kuroki, and G. Warren. 1996. Cold responses of Arabidopsis mutants impaired in freezing tolerance. J.Expt. Bot. 47:1919_ 1925.

Medina, J., M. Bargues, J. Terol, M. Perez-Alonso, and J. Salinas. 1999. The Arabidopsis $C B F$ gene family is composed of three genes encoding AP2 domain-containing proteins whose expression is regulated by low temperature but not by abscisic acid or dehydration. Plant Physiol. 119:463-469.

Monroy, A.F., Y.Castonguay, S. Laberge, F. Sarhan, L.P. Vezina, and R.S. Dhindsa. 1993. A new cold-induced alfalfa gene is associated with enhanced hardening at subzero temperature. Plant Physiol. 102:873-879.

Rieger, M. 1989. Freeze protection for horticultural crops. Hort. Rev. 11:45-109.

Rodrigo, J. 2000. Spring frosts in deciduous fruit trees-Morphological damage and flower hardiness. Scientia Hort. 85:155-173.

Sakai, A. and W. Larcher 1987. Frost survival in plants: Responses and adaptation to freezing stress. Springer-Verlag, Berlin.

Sambrook, J. and D.W. Russell. 2001. Molecular cloning: A laboratory manual. $3^{\text {rd }}$ ed. Cold Spring Harbor Laboratory Press, Cold Spring Harbor, N.Y.

Stockinger, E.J., S.J. Gilmour, and M.F. Thomashow. 1997. Arabidopsis thaliana $C B F 1$ encodes an AP2 domain-containing transcriptional activator that binds to the C-repeat/DRE, a cis-acting DNA regulatory element that stimulates transcription in response to low temperature and water deficit. Proc. Natl. Acad. Sci. USA 94:1035-1040.

Sukumaran, N.P. and C.J. Weiser. 1972. An excised leaflet test for evaluating potato frost tolerance. HortScience 7:467-468.

Tao, R., H. Yamane, A. Sugiura, H. Murayama, H. Sassa, and H. Mori. 1999. Molecular typing of S-alleles through identification, characterization and cDNA cloning for S-RNases in sweet cherry. J. Amer. Soc. Hort. Sci. 124:224-233.

Thomashow, M.F. 1999. Plant cold acclimation: freezing tolerance genes and regulatory mechanisms. Annu. Rev. Plant Physiol. Plant Mol. Biol. 50:571-599.

Thomashow, M.F., S.J. Gilmour, and E.J. Stockinger. 2001. Role of the Arabidopsis CBF transcriptional activators in cold acclimation. Physiol. Plant. 112:171-175.

Warren, G., R. McKwon, A. Mario, and R. Teutonico. 1996. Isolation of mutations affecting the development of freezing tolerance in Arabidopsis thaliana (L.) Heynh. Plant Physiol. 111:1011-1019.

Weiser, C.J. 1970. Cold resistance and injury in woody plants. Science 169:1269-1278.

Yamaguchi-Shinozaki, K. and K. Shinozaki. 1994. A novel cis-acting element in an Arabidopsis gene is involved responsiveness to drought, low-temperature, or high-salt stress. Plant Cell 6:251-264.

Willis, T.G., D.M. Jadayel, L.J.A. Coignet, M. AbdulRauf, J.G. Treleaven, D. Catovsky, and M.J.S. Dyer. 1997. Rapid molecular cloning of rearrangements of the IGHJ locus using long-distance inverse polymerase chain reaction. Blood 90:2456-2464.

Wisniewski, M., R. Webb, R. Balsamo, T.J. Close, X.M. Yu, and M. Griffith. 1999. Purification, immunolocalization, cryoprotective, and antifreeze activity of PCA60: A dehydrin from peach (Prunus persica). Physiol. Plant. 105:600-608. 